\title{
Ecological Ethics of Green Economy in Modern Society
}

\author{
Shuxia Zhang ${ }^{1}$ \\ ${ }^{1}$ Library, Zhengzhou Institute of Technology, China
}

Keywords: Green; Scientific And Sustainable; Ecological Harmony.

\begin{abstract}
The green economy is one of the main features of modern society which calls for the sustainable development. Ecological Ethics,being a major and common topic in human daily life, reflects the requirement by the nowadays environment in which human beings inhabit. This kind of economic development model has an obvious orientation of ecological ethics, which centers on innovation of energy technology, cares for ecosystem innovation and the fundamental change of concept of quality of life, and is in accordance with the requirements of the national development concept, i.e. the ecological harmony in China's scientific development. The green characteristics, which are reflected in every aspect of the social, ecological and economic features of coordinated development, reflect the overall concept of scientific development containing the systematic relationship of the whole society. The three aspects above-mentioned are complementary with each other. Simultaneous, they check each other based on sustainability of society, economy and ecology. Nowadays society is featured by people first and calls for green economy, in which, the development of high-tech industry and all kinds of green economy are considered as strategic development patterns, enhancing the competitiveness of high-tech products. As a result, the citizens should observe ecological ethics and live in green patterns, fostering the green awareness and moral. The nation should carry out ecological economy, green industry and serious green strategies.
\end{abstract}

\section{Introduction}

Xi Jin-ping has made more than 60 remarks and comments on building ecological security and maintaining ecological civilization since the 18th national congress. The Green Economy becomes one of most common topic. Xi Jin-ping points outs that green is the necessary and sustainable development concept, of which, green development philosophy is the focus. He often stresses that the green is a necessary condition of sustainable development, which is the important embodiment of people's pursuit of a better life. To Xi Jin-ping, green mountain and green water are gold and silver. Ecological civilization is regarded the center on innovation of energy technology. The whole country cares for ecosystem innovation and the fundamental change of concept of quality of life, and is in accordance with the requirements of the national development concept, i.e. the ecological harmony in China's scientific development. Academic analysis pointes out that the concept of green development is the innovative concept, which is the law of development that we must grasp. We must clear about the new situation. Fortunately, the country's political system demonstrates the ability to act wisely.

These years, we have established close friendship with the world's nearly 200 countries and regions to face the environmental problems. We also actively attended summit meetings that were about environmental problems. The purpose of these meetings was trying to control greenhouse gas emissions. The severe situation calls for the countries of the whole globe to reach a worldwide agreement ,or a global framework to cope with environmental crisis. And the only purpose of these efforts is to save the humankind. Above all, these efforts of the mankind will have a decisive influence on ways of the daily life of common people. And definitely, the purpose of these efforts is beneficial to the Earth's future climate, although the outcome of these meeting were not so satisfactory. Nowadays more and more people lead a more green life which will accordingly cause other people to get the awareness on the environmental problems of their current way of production and their life. 


\section{A concern about Green Economy in the new century}

After the agricultural and industrial civilization, Green Economy, or Green economy, is often viewed as another important progress of social model and economic development in human society. The green economy is one of the main features of modern society which calls for the sustainable development. Ecological Ethics,being a common and major topic in human daily life, reflects the requirement by the nowadays environment in which human beings inhabit. Based on low pollution, low power consumption and low emission, this power consumption model makes full use of wind, solar, hydrogen and biology energy. This model regards energy technology innovation, the focus shifting from consumption to the systematic innovation and a fundamental concept of human development. The destination of innovation is to improve energy efficiency or to renew energy structure. This kind of economic development model has an obvious orientation to call for the ecological ethics, which centers on innovation of energy technology, cares for ecosystem innovation and the fundamental change of concept of quality of life, and is in accordance with the requirements of the national development concept, i.e. the ecological harmony in China's scientific development. The green characteristics, which are reflected in every aspect of the social, ecological and economic features of coordinated development, reflect the overall concept of scientific development containing the systematic relationship of the whole society.

The model of green economy, in China, not only provides an operational interpretation for the purpose of energy saving, but also means the reconstruction of a harmonious society and the development of circular economy. To the scientific development concept, it is also a chance for people to think about how to build a conservation-oriented society. The green economy is completely consistent with the development idea embodied in the Party's 18th Congress Report and is the only way of sustainable economic development. Green economy is acknowledged as the global revolution these days , in production, lifestyle and values. The green economy is one of the main theme of the "fifth wave of global industry", according to a well-known scholar, Lin Hui, whose intension of green includes green society, green economy, green living doctrine, green philosophy, green art, and green lifestyle.

In China, since the 18th national congress, adhering to the green development becomes one basic national policy, in which, green resource conservation , environmental protection and sustainable development are the key words. As a fact, early in 2006, six ministries including the Ministry of Science jointly issued "the National Assessment Report on Climate Change" for the first time. Later, the seminar was held in Beijing with the topic of green economy and China's environmental policy. And then, “Long-term Renewable Energy Development Plan” was issued by the National Development and Reform Committee, in which, the development of hydro and wind power and other renewable energy sources are encouraged and supported.

Today, Xi Jin-ping stressed the importance of green mountain and green water. The nation has ever proposed the some suggestion: environmental protection technology, energy conservation technology and green energy technology to cope with the global climate problems. Just in the same time, the Minister of the National Science and Technology, at the annual meeting of Chinese Association for Science, called for great efforts to develop green economy. China's green network was established in China in early 21st century.

\section{Green Economy concept: the ecological - oriented ethics of social development}

Since the 18th national congress of the Communist Party, green economy, advocating low energy consumption and low pollution and low emission model, is in fact consistent with the scientific development concept in China. Both of green economy and scientific development emphasize the same expectations, economical development, ecological development and harmonious development. Scientific means paying special attention to ecological harmony, and thus is suitable for the green economy development. Based on current situation home and abroad, it is very urgent for us to carve out a new way of development and create a new model of development. It is a challenge as well as an opportunity for China today to construct an ecological civilization. Scientific development concept 
can be regarded as another civilization, in which, the society is on the basis of green development. But the facts is very severe, although it is the socialist harmonious society. We must do something, because scientific development concept is a humanist- value- orientated concept, which should and must answers a series of unavoidable questions, just like what, or how, or for whom to develop. Ecological and harmonious development is nothing but green development.

Scientific development concept, as the basis of social economic and ecological sustainability , is often characterized by a coordinated systemic interrelationship of society, economy and ecology. The core of this concept is human beings' long-term interests, which are consistent with the green economy requirement and purpose. Moreover, scientific development concept is also consistent with green economy in the same value orientation with social development with ecological ethic concern. The basic part of scientific development concept is the scientific idea about the relationship and co-existence between humankind and nature.

Through analysis of requirements and characteristics of green economy, we can find that social development has the obvious ecological ethic dimensions. By comparison the ecological views of Marxist with the perspective of green economy, we find that China's ecological ethics construction is in accordance with the scientific development. The concept of green economy has not only the practical significance, but also the theoretical significance. Scientific development emphasizes the construction of ecological ethics on the basis of development. To develop the productive forces is the primary task but it is not the whole purpose. Ecological ethics construction calls for better protection for the ecological environment.

Ecological ethics advocates ecological benefits. Today we must be aware that what are the ultimate purposes of the long-term interests of the whole humankind. So, it is basically for ecological benefits to human concerns to meet the constant interests' needs of human beings of the whole globe, which were once restricted access to nature because of ecological crisis. In China's development, it is to be realized that the government must maintain and develop the fundamental interest of the overwhelming majority of the people and ecological ethics construction and the people-oriented values must be fully embodied.

Abiding by scientific development concept, China has established harmonious perspective for the ecological ethics construction. The government has already pointed out the direction for the development of green economic and it is also the developing direction for harmonious society. The word, harmony, translated by using scientific development concept, has two dimensions. One is ecological nature and the other is ecological humanities. The former pursues harmony between man and nature and the later pursues the harmony among human beings. Ecological ethics construction will strengthen ecological humanities content, unifying the harmony between nature and human being.

\section{Pressure and recriminations: ecological and harmonious countermeasures}

At present, the data of energy consumption carries a lot pressure. Emission reduction task and energy conservation pressure are extremely severe at present. Energy-saving pressure is stern And energy utilization efficiency is not so satisfactory. Although we have made great progress during 2010-2015, according to statistics, China's GDP accounts for 6\% off the world from 1990 to 2007. With rapid national economic growth and with the rapid development of heavy industry, energy consumption in this country carries a lot pollution. Regarded at the energy consumption rate, by 2020, China's energy demand will reach 41.8 million ton, according to Zhuang Guiyang(2009) . It is estimated that energy demand will continue to increase. There is a prediction just as following list concerning carbon dioxide emissions in 2010-2030 in some countries and regions (table 1). We can find that China is facing the great pressure from carbon dioxide emissions. In the front of such pressure, the central government has settled out establishing national green economic strategy, calls for the whole society to be aware the severe situation about carbon dioxide emissions, and guides the action of the enterprises and residents . 
Table 1: some countries (regions)carbon dioxide emissions in 2010-2030 (forecast) Unit: million tons

\begin{tabular}{|l|l|l|l|}
\hline Countries/regions & 2010 & 2020 & 2030 \\
\hline Canada & 669 & 727 & 784 \\
\hline American & 6011 & 6384 & 6851 \\
\hline Japan & 1196 & 11495 & 1170 \\
\hline 15 states of the European Union & 4512 & 4760 & 4834 \\
\hline India & 1938 & 2614 & 3237 \\
\hline China & 6898 & 9475 & 12007 \\
\hline The world & 31100 & 37035 & 42325 \\
\hline
\end{tabular}

(Data source: Zhuang Guiyang, the analysis of the difficulties and obstacles of China's development of green economy, Jiangxi social science, 2009)

Viewed from green economy practice, the world needs not only the harmonious social environment, but also the harmonious natural environment. So, the mankind from different countries has the same purposes and requirements of development of the better life. Nowadays, how to promote green economy and how to promote green environment are the same tasks for the people all of the world.

Firstly, we know that fossil fuels, such as coal, oil, etc., are still the main sources though they are limited greatly at present. But in the future quite a long period of time, they are considered as important component in energy structure. As we can see, with the efforts of the government and the participation in international carbon trading, although energy consumption increasing, but ratio of the emissions of greenhouse gases is not so high. although it will continue to grow for some period. At present, in the process from "high carbon" to "green", we should transform the traditional industry with new technology. On one hand, we should reduce consumption of fossil resources, reducing pollution to the environment. On the other hand, we should actively develop high-tech industry structure, carrying out the green growth strategies. Meanwhile, the government of China must create new poles of economic growth, accelerating green industry development such as modern service industry and so on. To improve and upgrade the first and second industry structure is particularly important. First of all, we should develop hi-tech industry universally, moderating the import and export strategies.

Secondly, we should develop green morals and national green awareness. The climate conference in Copenhagen and today's world witness the Chinese people's determination and responsible attitude to green life. Green society and green economy have become an everyday topic and universally paid attention. Economic situation is not so optimistic that needs immediate positive "green action" and needs a responsible attitude to the near future. The government should nationally and responsibly cultivate his citizens with green awareness and green morals. It is the severe satiation that calls for responsible attitude and immediate action. "Green action" should be on the way right now. This kind of action is of ethical and moral meaning, which has been acknowledged by almost all the people. The people know clearly than ever before that green and the quality of life are closely linked to their life..

Thirdly, China has made more and more on building ecological security and maintaining ecological civilization since the 18th national congress. Xi Jin-ping points out the importance for many times in different situation and occasion. The Green Economy becomes one of most common topic. As the necessary and sustainable development concept, the word "green" is the focus of theme of the whole world. The green characteristics, which are reflected in every aspect of the social development, also embodied in ecological development, reflecting the overall concept of scientific development. In one word, with green characteristics, the whole society contains the systematic and harmonious relationship everywhere, every time. Society, economy and ecology, the three aspects mentioned above are complementary with each other. Simultaneous, based on sustainability, the three aspects check each other. Nowadays society is featured by people first and calls for green economy, 
in which, the development of high-tech industry and all kinds of green economy are considered as strategic development patterns, enhancing the competitiveness of high-tech products. The nation should carry out ecological economy, green industry and serious green strategies, and the citizens should observe ecological ethics and live in green patterns, fostering the green awareness and moral. And as a result, there is a bright future in front of us, the whole mankind.

\section{References}

[1] Wang Ruo. Europe Ecology [M]. Beijing: Peking University Press, 2003:4.

[2] Hou Huiqin. On the Significance of Scientific Development [J]. Marxism Research, 2006 (6): 22-26.

[3] Xi Jinping: The Governance of China [M]. Beijing: Foreign Language Press, 2014. 